\title{
Role of vocational and technical training in achieving gender equality and empowering all women and girls: An empirical study of Sindh, Pakistan
}

\author{
I. Abid ${ }^{1 *}, K . A$. Afaq $^{1}, S$. Atif $^{1}, M$. Sana $^{1}$ and $A$. Saiqa $^{2}$ \\ ${ }^{1}$ Economics and Finance Department, Mohammad Ali Jinnah University, Karachi 75400, Pakistan. \\ ${ }^{2}$ Information Technology Centre. Sindh Agricultural University. Tandojam. Pakistan.
}

\begin{abstract}
Trained and technically equipped human resources are the nations' assets and an essential requirement for sustainable national development. The skilled labor force required for the industrial revolution can never be undermined while it can be used as a powerful weapon for poverty reduction. Women presenting almost half of the world population can be economically empowered through vocational and technical training and the fifth sustainable development goal "achieving gender equality and empowering all women and girls with disabilities" can be achieved through this training. Different vocational and technical training programs have been proven to produce technically skilled human resources in different developing countries. However, such programs also have the limitations of accommodating a high percent of trainees in jobs or self-employment. The study aimed to sort out the determinants of these training programs' low success rates in Sindh province of Pakistan. A total of 128 surveys were filled from randomly selected women who have completed their trainings in the last two years. Data were analyzed through cross-tabulation analysis on SPSS and AMOS. It is used to establish the relationship between training trades and employability, age group and employability and income group of the beneficiaries' households, and their employability after completing the different technical and vocational training pieces. Results showed that around $35 \%$ of the selected women were ever employed after getting the training while significant relationships among the variables also resulted. It has been proven that the importance of technical and vocational training programs cannot be falsified. However, proper selection criteria must be followed, and only severe and needy beneficiaries should be selected through proper assessment. Need assessments for the training programs should be carried out while efforts for achieving employment as an outcome of such training programs are mandatory.
\end{abstract}

* Corresponding author: abidiqbal.apex@gmail.com 


\section{Introduction}

Due to technological advancement, the world is now considered as global village and nations can never survive without adopting the modern techniques required in practical life. On the other hand, women represent almost half of the world's population and could never compete in economic development if ignored by any nation. The $5^{\text {th }}$ sustainable development goal is also emphasized on gender equality and women's and girl's empowerment. Although general education is mandatory for humans but without getting technical education, the required skills for the advanced job market cannot be attained. The technical and vocational education and training refer to the type of education that stresses applying the skills, knowledge and attitudes needed to work in a particular profession or a group of interrelated professions in any area of social and economic activity [1]. These are the different education features that integrate technological sciences and the attainment of practical knowledge and attitude with general education. Enhancing skills and attitudes about different practical professions in the economy and practical life is mandatory to survive in the technological era [2]. The technical and vocational education and training prepare the persons by providing or increasing the required skills, knowledge, and attitudes required to work and survive in a competitive age [3]. As per the world bank's data from different official resources, women represent $48.54 \%$ of the total population of Pakistan [4] but the women's literacy rate in Pakistan is shallow. An only a lesser percentage of women move to higher secondary education and technical skills. The share of women to household livelihood is also meagre.

Donors are increasingly recognizing the importance of Technical and Vocational Education and Training in driving economic and social development and indulge the major chunk of the population, i.e. young / adult women in the country's employment. As a result, there is a need for more and new TVET policies and support to training structures through improved international cooperation. Over the last decade, more and more children in developing countries have received a primary education level. This has created pressure on governments and donors to provide more secondary, technical and vocational training, specifically for young women who are deprived of higher educational opportunities, that helps them acquire skills, knowledge and attitudes needed to develop professional careers and enter the world of work, creating a vibrant labor market and contributing to economic growth. Many research studies have been conducted worldwide to study the relationship between socio-economic conditions of the population and technical and vocational education for young adult women for better livelihood opportunities. Although new policies, better support and improved cooperation requires more significant agreement amongst partner on several TVET issues, such as;

- Need and demand analysis concerning the local specific context with particular attention to the informal economy,

- A key role of the private sector as a significant player in TVET in developing and implementing the institutional framework,

- The importance of a solid education foundation coherent with adequate employment policies and complemented by specific measures to facilitate access to the labour market for employees and market

- Credit facilities for entrepreneurs

- Further development of validation and certification to improved skills recognition

- Employability and better mobility,

- $\quad$ support to regional initiatives and better sharing of experiences and knowledge to help develop national efforts. 


\subsection{Women in Pakistan}

As per the 2017 census of Pakistan, the women population is $48.76 \%$ of Pakistan's total population. Bari mentions it, F. [5] in the country's briefing paper that the status of women in Pakistan is not similar and there is multiplicity in the women's status across classes, regions and rural/urban division to irregular socio-economic development. The low level of education, health and nutrition make the women more vulnerable. However, the condition prevails with women with no or meager income. Poverty also forces women to work harder for the earning and protection of their families. It is estimated that two-thirds of the psychiatric patients at any hospital or clinic are women. Women's poor mental and physical health has negative implications on their productivity and imposes high social and economic costs for society. Sadaquat, M. B. [6] stated that working women in Pakistan facing the problem of market discrimination and compel to low paid and low-status jobs. The rate of unemployment among women is consistently higher than men.

\subsection{Statement of the problem}

Technical and Vocational education has long-lasting impacts on the country's sociological, economic, financial, and political aspects. The purpose of TVET is to impart technical skills and conceptual knowledge to young women and empower adult / young women to contribute to their societies and live at least better life. Many aspects could be studied in order to reach the expected results.

- $\quad$ Age group

- Income group

- Employment Opportunities

- Willingness to work/employability

- Entrepreneurship Opportunities

This research aims to determine the impact of donor funding and TVET on women's livelihood in the area.

\subsection{Significance of the Study}

This research study is so essential as it intended to determine the impact of Technical and Vocational training on the lives of adult / young women's livelihood and fair opportunities for targeted segments with respect to donor-funded projects. This research may help funding agencies for proper selection criteria for identifying potential beneficiaries, who may extend learned skills and knowledge for better livelihood, Government \& Administration for policymaking in order to spend funds effectively for TVET, Policy formulation for the private-public partnership for TVET and industries for skilled labor force availability in the market.

\subsection{Research questions}

The following research questions are answered from the data

- Is there any positive relationship between donors funded technical and vocational education projects on young women's better livelihood in nonformal settings?

- Is the selection criteria or effective selection of beneficiaries have an impact on the projects' success.? 
- Is the market survey critical before designing and launching the training program?

- Is there any positive link between age group of the trainees and the success of training programs?

- Is there any relationship between the income group of the trainees and the success of the training projects?

\subsection{Literature Review}

Technical and vocational training is the best way to enhance the country's labor force's technical knowledge and skills. Women can especially be empowered by making them skilled to serve in the industry or start their own business. As per Oyebolu et al. [7] the Technical and Vocational education prepares trainees for job engagements by providing them the required knowledge, skills and attitudes. S.O. Chukwuedo et al. [8] stated that technical and vocational education and training programs help produce the demand-driven laborer for achieving the objective of sustainable industrial and technological development. It is reviled by Audu et al. [2] that eradication of unemployment is a challenge for developing and high populated nations. However, it can be reduced through well organized and resentful technical and vocational programs. These programs are helpful in production of wealth, creation of job opportunities and sustainable livelihood. Iqbal. A et al. [9] said that poverty and underdevelopment are due to fewer opportunities for unemployment. However, the issue can be overcome by creating employment opportunities by providing training to local people on different required skills. It is stated by Afeti [10] that different stakeholders like Government, Training organizations, caretakers of the trainees, potential employers, and implementing partners have to play their role for practical technical and vocational training. As per Raji [11] proper policies and procedures are mandatory for the successfulness of technical and vocational training and skills provided to youth. It should focus on the relevance of training, job market or opportunities, linkages with potential employers, acceptable certification, monitoring, evaluation, accountability and learning, training of the trainers and the most essential funding required for program implementation.

\subsection{Theories of learning}

The following theories described the concept of technical and vocational learning.

\subsubsection{Theory of Lifelong learning}

A grounded theory presented by Ridzwan et al. [12] described that the notion behind vocational and technical training is to acquire the skills which make the trainees to get the jobs quickly. However, these skills can only be achieved by passing through five stages i.e. Enter, Accept, Adopt, Change and Skills required for jobs. These steps form the vocational skill that genuinely supports the idea of lifelong learning. The last stage of the theory is purely supporting the study as the trainees who acquired the skills should also serve in the filed by the employment or through establishing small scall businesses. However, stakeholders like govt. implementing organizations and employers should also play their role by offering the employment opportunities and accommodating the trainees through micro-credit etc.

\subsubsection{Ladder of participation and mastering}


Concept of participation and mastering is presented by Ryberg and Christiansen [13] by describing the four stages of leaning. A learning ladder starts from tiptoeing to gradually mastering and becoming expert in the skills and at the last step of the ladder is teaching to others in the community. However, this theory missed out the employment requirement, which should be the final stage of the learning as the master also have to serve by applying their learnings practically. Moreover, becoming master or trainer of any trade is time taking process which should be defined. A three to six months' training can never make the trainees as master of the trade.

\subsubsection{Outcome-based learning theory}

Spady et al. [14] presented a well-known theory called outcome learning theory, which was basically presented for classroom learning. However, it can be linked with all types of learning processes. The researchers discussed the learning outcome goals, assessment and reporting, course outline, teaching methodology, success-oriented record keeping and program evaluation. The same can be linked with the nonformal education system and technical and vocational training programs. All the training programs' success is linked with the ultimate objectives of applying the learned skills for wealth production and earnings. The programs can only be considered successful when they achieved a high level of employment of the trainees. The outcome of all the training programs in both the short and long term is the trainees' economic empowerment.

\subsection{Training Vs. Employment}

Usman Mustafa et al. [15] stated that the technically equipped human resource supply and demand in Pakistan are not marching. Universities are producing many graduates in nontechnical subjects while the job market requirement is different. The public sector cannot produce the job opportunities, and vocational and technical training institutes are not giving the lots equipped with required technical skills. Further, due to the high unemployment level and lack of opportunities, the skilled force is migrating to the middle east and other states. They recommended that a policy be made for technical programs development and implementation. It should be assured through continuous data collection that the trainees' skills are meeting the current requirements. Mansfield [16] established that vocational and technical training help prepare young people for the job market in the economy but entrepreneurial skills are also mandatory for them. It is proved by them that along with technical skills, the requirement of essential and business skills is also severe issues. P.N. Yangben et al. [17] described the importance of technical training employment from a descriptive survey. They resulted that training programs can only achieve the set objectives, if training institutes are adequately equipped with the required resources. Linkages should be developed among the industries and other employers and the training organizations to accommodate the job market trainees. It is recommended by Christina Boateng [18] that wellequipped coordinators are required for the vocational and technical programs. They should keep the coordination amongst the different stakeholders including government, training institutions and the industry for establishing the partnership. They may be responsible for creating linkages among the technical and vocational training and the labor market. The effective delivery of technical and vocational training can be assured through the coordinators who will be considered the leaders. 


\subsection{Trainees selection criteria and employment opportunities}

Availability and application of the proper selection criteria are a must for vocational and training programs' success. The vulnerable beneficiaries should be selected on a merit basis and should be supported until sustainability. Celestin Mayombe et.al [19] described the purposes of the training programs, monitory capabilities of the training institutes, proper selection of the trainees, training need assessments, and environment for acquiring the skills and employment end are interrelated. The training institutes should offer and provide the training which is matching with the current market requirement. They suggested that the trainers and organizers should work with a clear objective of providing skills for jobs or selfemployment according to the age of trainees. Trainees should be selected based on the wellassessed needs of the candidate and market requirement. Immediate income generation right after completion of training should be the explicit goal of the training program. As discussed by John Aitchison [20], internal factors are mandatory for achieving adults training programs' success. It is abstracted by Mayombe [21] that managers failed in creating good linkages with different potential employers and other institutions for providing the necessary support to trainees after their graduation. He argued that without linkages development with external stakeholders, the trainees will always face the problem in the settlement of small businesses or getting the relevant jobs in the market.

\subsection{Technical and vocational training for women empowerment}

Diwakar N. et al. [22] stated that technical and vocational training is the prevailing instrument against poverty, hunger, and empowerment. Such programs can support the poor and women by increasing households' productivity, employability, and creating earning opportunities. It is also helpful in the sustainability of the environment and the creation of livelihoods. Johnson [23] stated that vocational training programs are the key to rural women empowerment and poor women welcome the programs which help in income generation. Zia Ullah et al. [24] shared that socio-cultural barriers are blocking women empowerment ins few areas which can be resisted by molding social values in favor of women empowerment with the support of education, income opportunities and providing the decision making power.

\section{Method}

It was an empirical study and a survey tool based on respondents' demographic information and nine Likers scale questions about the subject matter were used for data collection. A total of 128 surveys were filled by approaching randomly selected women. These nominated females got training in different trades like Beautician, Dress Making, Early Childhood Education, Office Management and Web Designing from different institutes of Sindh province of Pakistan. Such training programs were funded by different donor organizations and provincial and national governments. The collected data were analyzed by applying cross-tabulation frequency analysis on the statistical package for social sciences (SPSS) and likelihood and relationship amongst the variables was tested through analysis of a moment structure (AMOS) by applying simple linear regression. Study was based on four variables where the success of the training programs was taken as dependent variable. Independent variables include training trades, age group and household income group of the trainees. 


\section{Results and discussion}

Results drawn from cross-tabulation frequency analysis answered five research questions about trained women's livelihood situations on different skills. Case processing summary resulted in $100 \%$ valid cases and no case was observed missing. Likelihood estimates of the model were resulted through AMOS.

\subsection{Maximum likelihood estimates}

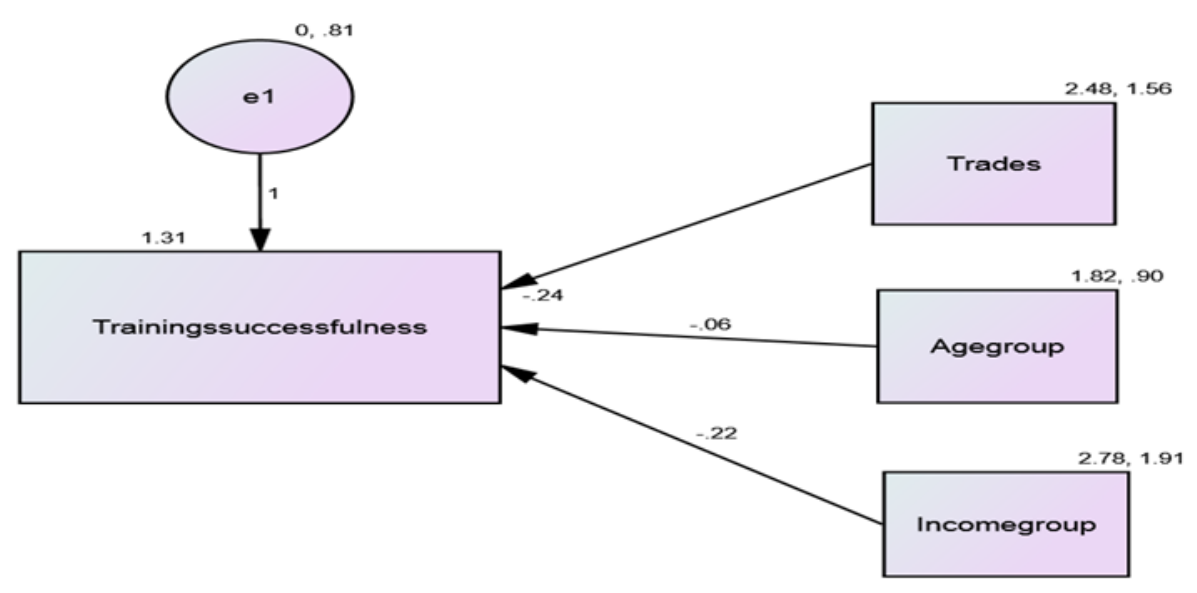

Fig. 1. Maximum likelihood estimates.

The results indicate that the beneficiaries' training trades and income group have a significant adverse effect on the training programs' success as $p$ values of both the variables were less than .05. Age group of the trainees has not proved a significant impact but it was due to the number of trainees who have rejoiced the formal education. Trainees who went back for formal education were also considered as success of the training programs. However, cumulative effect of all the predictors on the dependent variable drawn through ANOVA has shown the significant impact with less than $.05 \mathrm{p}$-value. So, it has been proven that proper selection criteria for the beneficiary selection impact the success of the training programs and must be considered at the time of planning and implementation.

\subsection{Cross-tabulation results}

Results drawn by conducted cross-tabulation analysis on SPSS are as under:

\subsubsection{Training trades and employment}


Table 1. Relationship between training trades and employment of trained women

\begin{tabular}{|c|c|c|c|c|c|c|c|c|}
\hline & & $\begin{array}{c}\text { Ever been } \\
\text { employed } \\
\text { after } \\
\text { training }\end{array}$ & $\begin{array}{c}\text { Looking } \\
\text { for } \\
\text { chances } \\
\text { of job }\end{array}$ & $\begin{array}{c}\text { Tried for } \\
\text { starting } \\
\text { business }\end{array}$ & $\begin{array}{c}\text { Using } \\
\text { acquired } \\
\text { skills for } \\
\text { non- } \\
\text { commerc } \\
\text { ial basis }\end{array}$ & $\begin{array}{l}\text { Enrolled } \\
\text { for further } \\
\text { education }\end{array}$ & $\begin{array}{l}\text { No } \\
\text { action } \\
\text { is } \\
\text { taken }\end{array}$ & Total \\
\hline Beautician & Count & 16 & 3 & 5 & 4 & 1 & 0 & 29 \\
\hline Dressmaking & $\begin{array}{c}\% \text { within Trades } \\
\text { Count } \\
\% \text { within Trades }\end{array}$ & $\begin{array}{l}55.2 \% \\
19 \\
35.2 \%\end{array}$ & $\begin{array}{l}10.3 \% \\
17 \\
31.5 \%\end{array}$ & $\begin{array}{c}17.2 \% \\
5 \\
9.3 \%\end{array}$ & $\begin{array}{c}13.8 \% \\
5 \\
9.3 \%\end{array}$ & $\begin{array}{c}3.4 \% \\
1 \\
1.9 \%\end{array}$ & $\begin{array}{c}0.0 \% \\
7 \\
13.0 \%\end{array}$ & $\begin{array}{c}100.0 \% \\
54 \\
100.0 \%\end{array}$ \\
\hline $\begin{array}{l}\text { Early Childhood } \\
\text { Education }\end{array}$ & $\begin{array}{c}\text { Count } \\
\text { \% within Trades }\end{array}$ & $\begin{array}{c}4 \\
40.0 \%\end{array}$ & $\begin{array}{c}4 \\
40.0 \%\end{array}$ & $\begin{array}{c}0 \\
0.0 \%\end{array}$ & $\begin{array}{c}0 \\
0.0 \%\end{array}$ & $\begin{array}{c}1 \\
10.0 \%\end{array}$ & $\begin{array}{c}1 \\
10.0 \%\end{array}$ & $\begin{array}{c}10 \\
100.0 \%\end{array}$ \\
\hline Office & Count & 6 & 7 & 0 & 1 & 6 & 5 & 25 \\
\hline Administration & $\%$ within Trades & $24.0 \%$ & $28.0 \%$ & $0.0 \%$ & $4.0 \%$ & $24.0 \%$ & $20.0 \%$ & $100.0 \%$ \\
\hline Web designing & $\begin{array}{c}\text { Count } \\
\% \text { within Trades }\end{array}$ & $\begin{array}{c}0 \\
0.0 \%\end{array}$ & $\begin{array}{c}4 \\
40.0 \%\end{array}$ & $\begin{array}{c}0 \\
0.0 \%\end{array}$ & $\begin{array}{c}0 \\
0.0 \%\end{array}$ & $\begin{array}{c}5 \\
50.0 \%\end{array}$ & $\begin{array}{c}1 \\
10.0 \%\end{array}$ & $\begin{array}{c}10 \\
100.0 \%\end{array}$ \\
\hline \multirow[t]{2}{*}{ Total } & Count & 45 & 35 & 10 & 10 & 14 & 14 & 128 \\
\hline & $\%$ within Trades & $35.2 \%$ & $27.3 \%$ & $7.8 \%$ & $7.8 \%$ & $10.9 \%$ & $10.9 \%$ & $100.0 \%$ \\
\hline
\end{tabular}

As per the results drawn from data analysis, only $35 \%$ of the interviewed women were either employed or employed after completing the training. Employment includes both job and business. Very few respondents (around 8\%) tried for starting their businesses while 27\% said that they applied for the job but have not received any response from the potential employers. Around $8 \%$ of women reported using acquired skills noncommercially by providing the free of cost services to their family members, relatives and other community members etc. Around $11 \%$ of women went for further education as either they were mobilized during the training or completed the training during vacations while the same $11 \%$ of women have not taken any action. If we go for the trade wise comparison, beauticians are the only training that reaches $55 \%$ of employment and have better results compared to other trades. $40 \%$ of the beneficiaries who were trained on early childhood education joined the jobs or doing their own business but as shown in the table number of respondents from ECE trade was very low. Dress making showed better results as $35 \%$ of respondents were either employed or doing their own business at a small scale. $24 \%$ of respondents who did the training on office administration were employed but all the respondents of web designing were not employed, however $50 \%$ of them enrolled for further education. 


\subsubsection{Age group and employment}

Table 2. Relationship between age group and employment of trained women

\begin{tabular}{ccccccccc}
\hline & & $\begin{array}{c}\text { Ever been } \\
\text { employed } \\
\text { after } \\
\text { training }\end{array}$ & $\begin{array}{c}\text { Looking } \\
\text { for } \\
\text { chances } \\
\text { of job }\end{array}$ & $\begin{array}{c}\text { Tried for } \\
\text { stating } \\
\text { business }\end{array}$ & $\begin{array}{c}\text { Using acquired } \\
\text { skills for a } \\
\text { non- } \\
\text { commercial } \\
\text { basis }\end{array}$ & $\begin{array}{c}\text { Enrolled } \\
\text { for } \\
\text { further } \\
\text { education }\end{array}$ & $\begin{array}{c}\text { No action } \\
\text { is taken }\end{array}$ & Total \\
\hline \multirow{2}{*}{$15-20$} & Count & 18 & 14 & 5 & 6 & 12 & 7 & 62 \\
& \% within Age group & $29.00 \%$ & $22.60 \%$ & $8.10 \%$ & $9.70 \%$ & $19.40 \%$ & $11.30 \%$ & $100.00 \%$ \\
$21-25$ & Count & 18 & 7 & 3 & 3 & 1 & 4 & 36 \\
& \% within Age group & $50.00 \%$ & $19.40 \%$ & $8.30 \%$ & $8.30 \%$ & $2.80 \%$ & $11.10 \%$ & $100.00 \%$ \\
$26-30$ & Count & 8 & 8 & 2 & 0 & 1 & 2 & 21 \\
& \% within Age group & $38.10 \%$ & $38.10 \%$ & $9.50 \%$ & $0.00 \%$ & $4.80 \%$ & $9.50 \%$ & $100.00 \%$ \\
$31-35$ & Count & 1 & 6 & 0 & 1 & 0 & 1 & 9 \\
& \% within Age group & $11.10 \%$ & $66.70 \%$ & $0.00 \%$ & $11.10 \%$ & $0.00 \%$ & $11.10 \%$ & $100.00 \%$ \\
Total & Count & 45 & 35 & 10 & 10 & 14 & 14 & 128 \\
& \% within Age group & $35.20 \%$ & $27.30 \%$ & $7.80 \%$ & $7.80 \%$ & $10.90 \%$ & $10.90 \%$ & $100.00 \%$ \\
\hline
\end{tabular}

The age of the selected respondents was between 15 to 35 years. It is resulted from the data that respondents between the age group of 21-25 have achieved 50\% employability. Females of the age group of 26-30 year remain on second place with $38 \%$ of employment level. $29 \%$ women of 15-20 years of age have secured the jobs after completing their training. However, $66 \%$ of women of 31-35 years and 38\% women of 26-30 years applied for the jobs but have not succeeded. Significantly few percentages of different age groups have tried to start their own businesses. Same position is resulted about the women who were using the acquired skills on a non-commercial basis. The highest $19 \%$ women of $15-20$ years of age joined the educational institutes for enhancing their education. For almost all the selected age groups, $11 \%$ of women have not taken any action after completing the training.

\subsubsection{Income group and employment}

Table 3. Relationship between income group and the employment of trained women

\begin{tabular}{|c|c|c|c|c|c|c|c|c|}
\hline & & $\begin{array}{l}\text { Ever } \\
\text { been } \\
\text { employ } \\
\text { ed after } \\
\text { training }\end{array}$ & $\begin{array}{l}\text { Looking } \\
\text { for } \\
\text { chances } \\
\text { of job }\end{array}$ & $\begin{array}{c}\text { Tried } \\
\text { for } \\
\text { starting } \\
\text { busines } \\
\text { s }\end{array}$ & $\begin{array}{c}\text { Using } \\
\text { acquired } \\
\text { skills for } \\
\text { non- } \\
\text { commercial } \\
\text { basis }\end{array}$ & $\begin{array}{l}\text { Enrolled } \\
\text { for further } \\
\text { education }\end{array}$ & $\begin{array}{c}\text { No } \\
\text { action } \\
\text { is taken }\end{array}$ & Total \\
\hline \multirow{2}{*}{$0-10000$} & Count & 14 & 10 & 1 & 2 & 1 & 3 & 31 \\
\hline & $\%$ within Income group & $45.20 \%$ & $32.30 \%$ & $3.20 \%$ & $6.50 \%$ & $3.20 \%$ & $9.70 \%$ & $100.00 \%$ \\
\hline \multirow{2}{*}{$10001-20000$} & Count & 6 & 5 & 0 & 3 & 2 & 1 & 17 \\
\hline & $\%$ within Income group & $35.30 \%$ & $29.40 \%$ & $0.00 \%$ & $17.60 \%$ & $11.80 \%$ & $5.90 \%$ & $100.00 \%$ \\
\hline \multirow{2}{*}{$20001-30000$} & Count & 21 & 16 & 3 & 2 & 4 & 4 & 50 \\
\hline & $\%$ within Income group & $42.00 \%$ & $32.00 \%$ & $6.00 \%$ & $4.00 \%$ & $8.00 \%$ & $8.00 \%$ & $100.00 \%$ \\
\hline $30001-40000$ & Count & 3 & 2 & 4 & 2 & 3 & 3 & 17 \\
\hline
\end{tabular}




\begin{tabular}{ccccccccc} 
& \% within Income group & $17.60 \%$ & $11.80 \%$ & $23.50 \%$ & $11.80 \%$ & $17.60 \%$ & $17.60 \%$ & $100.00 \%$ \\
\multirow{4}{*}{$40001-50000$} & Count & 1 & 1 & 1 & 1 & 0 & 1 & 5 \\
& \% within Income group & $20.00 \%$ & $20.00 \%$ & $20.00 \%$ & $20.00 \%$ & $0.00 \%$ & $20.00 \%$ & $100.00 \%$ \\
\multirow{3}{*}{ Above 50000 } & Count & 0 & 1 & 1 & 0 & 4 & 2 & 8 \\
& \% within Income group & $0.00 \%$ & $12.50 \%$ & $12.50 \%$ & $0.00 \%$ & $50.00 \%$ & $25.00 \%$ & $100.00 \%$ \\
Total & Count & 45 & 35 & 10 & 10 & 14 & 14 & 128 \\
& \% within Income group & $35.20 \%$ & $27.30 \%$ & $7.80 \%$ & $7.80 \%$ & $10.90 \%$ & $10.90 \%$ & $100.00 \%$ \\
\hline
\end{tabular}

As shown in the table, the highest $45 \%$ of respondents who got employed after completion of training were 0-10000 rupees monthly household income. Women with 20001-30000 rupees monthly household income who got the jobs or started their businesses were $42 \%$ while 35\% of respondents with 10001-20000 rupees monthly household income enjoyed the jobs. As the number of women selected from 40001-50000 rupees monthly household income was deficient, $20 \%$ each got jobs, applied for jobs, tried for starting business, or had no action taken any serious action. 50\% of respondents with higher level of income (above 50000 rupees monthly income) enrolled for further education while $25 \%$ have not taken any action after training.

\section{Conclusion}

From the results, it can be concluded that selecting the training trades that have the demand in the job market is essential, otherwise trained beneficiaries may not get the chances of jobs or starting their own businesses. As shown in table 1. the beautician trade has more demand as $55 \%$ of the respondents were on the job or doing their businesses but no women from web designing was on job. It shows that some of the offered training courses did not have the market demand and work opportunities. Beautician also showed the highest results in applying the acquired skills non-commercial while beneficiaries of the same trade were leading in trying to start their businesses. Setting a proper trainee's selection criteria is also important. Results described that $50 \%$ of selected women of 21-25 years were on the job or operating their own businesses while women of 26-30 years of age were in the second position by $38 \%$ women securing jobs. Highest $19 \%$ women of 15-20 years of age were enrolled for further education. It indicates that adolescents were more interested in their regular education despite continuing with the skills they acquired from training. During the informal discussion, most young trainees disclosed that they don't want to continue training skills as professionals. Household income is another crucial aspect of trainees' selection. As indicated in table 3 most of the women with lower-income groups were on job. Most of the women with lower-income groups were in search of jobs. However, a higher percentage of women with higher income group went for regular education. It is good sign but the women with higher household income did not need the such training as they can afford the regular education and join the training sessions for passing their summer vacations.

Preparing a skilled workforce or human capital is very important for the economy's economic and social development. As women represent half of the population, they cannot be ignored and should be prepared to compete in the job market. Technical and vocational training programs help enhance the skills of the country's labor force while funding is also required for successful implementation of such programs. It is evident from the research study that before launching any training programs, market demand of the labor should be identified by conducting the detailed market survey. Though the survey, the potential employer should also be identified and linkage development should be integral to the programs. Entrepreneurship training should be focused, as most of the trainees were interested in getting jobs while a minimal number was interested in starting their own 
business. Proper selection criteria by focusing on income level and age group, etc. for trainees' selection is also recommended. Trainees from low- or average-income groups may take more interest in getting training and adopting it as a profession. Moreover, considering the age group which can adequately serve in the market should also be kept in mind while designing the training programs.

\section{References}

[1]. Eze CP (2013). Empowering the youth through technical and vocational education: A panacea for sustainable national development. Unizik Orient Journal of Education 7(1):59-64.

[2]. Audu, R., Kamin, Y. B., \& Balash, F. (2013). Technical vocational education: as a veritable tool for eradicating youth unemployment. International Organization of Scientific Research Journal of Humanities and Social Science, 8(2), 10-17.

[3]. Chijioke, O. P. (2013). Appraisal of theoretical models of psychomotor skills and applications to technical vocational education and training (TVET) system in Nigeria. Journal of Research and Development, 187(1471), 1-11.

[4]. https://tradingeconomics.com/pakistan/population-female-percent-of-total-wbdata.html

[5]. Bari, F. (2000). Women in Pakistan. Asian Development Bank, Programs Department (West) and Office of Environment and Social Development.

[6]. Sadaquat, M. B. (2011). Employment situation of women in Pakistan. International journal of social economics.

[7]. Oyebolu, S., \& Lemo, O. O. (2013). The impact of information and communication technology (ICT) on vocational and technical students' learning. Journal of Education and Practice, 4(7), 178-189.

[8]. Chukwuedo, S. O., \& Omofonmwan, G. O. (2015). Developing Industrial and Technological Manpower via Technical Vocational Education and Training (TVET) in Nigeria. University of Mauritius Research Journal, 21, 507-524.

[9]. Iqbal, A., \& Khan, A. A. (2020, May). Inclusive and sustainable community development and poverty reduction: An empirical study of Sindh, Pakistan. In IOP Conference Series: Earth and Environmental Science (Vol. 511, No. 1, p. 012005). IOP Publishing.

[10]. Afeti, G. (2009). Technical and vocational education and training for industrialization. In African Research and Resource Forum. Retrieved January (Vol. 25, p. 2012).

[11]. Raji, S. A. (2015). Technical and Vocational Skills Acquisition Training: An Imperative toward the Achievement of National Industrial Revolution plan. Journal of Education and Social Science, 1-8.

[12]. Rus, R. C., Yasin, R. M., Yunus, F. A. N., Rahim, M. B., \& Ismail, I. M. (2015). Skilling for job: A grounded theory of vocational training at industrial training institutes of malaysia. Procedia-Social and Behavioral Sciences, 204, 198-205.

[13]. Ryberg, T., \& Christiansen, E. (2008). Community and social network sites as technology enhanced learning environments. Technology, Pedagogy and Education, 17(3), 207-219.

[14]. Spady, W. G. (1982). Outcome-based instructional management: A sociological perspective. Australian Journal of Education, 26(2), 123-143.

[15]. Mustafa, U., Abbas, K., Saeed, A., \& Anwar, T. (2005). Enhancing Vocational Training for Economic Growth in Pakistan [with Comments]. The Pakistan Development Review, 567-584. 
[16]. Mansfield, B. (2003). Core and entrepreneurial skills in vocational education and training. From concept and theory to practical application.

[17]. Yangben, P. N., \& Seniwoliba, J. A. (2014). Career challenges in construction craft training in technical vocational education and training in Ghana

[18]. Boateng, C. (2012). Restructuring vocational and technical education in Ghana: The role of leadership development. International Journal of humanities and Social science, 2(4), 108-114.

[19]. Mayombe, C., \& Lombard, A. (2015). How useful are skills acquired at adult nonformal education and training centres for finding employment in South Africa? International Review of Education, 61(5), 611-630.

[20]. Aitchison, J. (2007). South Africa: Nonformal education. Country prole prepared for the Education for.

[21]. Mayombe, C. (2017). Integrated Non-Formal Education and Training Programs and Centre Linkages for Adult Employment in South Africa. Australian Journal of Adult Learning, 57(1), 105-125.

[22]. Diwakar, N., \& Ahamad, T. (2015). Skills development of women through vocational training. International Message of Applied Research, 1, 79-83.

[23]. Johnson, E. J. (2015). Empowerment of women through Vocational Training. Basic Research Journal of education Research and Review, 4(2), 37-44.

[24]. Akhunzada, Z. U., Khattak, M. K., \& Ashraf, A. (2015). Socio-Cultural Barriers to Empowerment: A Study of Working Women in Vocational Training Institutes of District Kohat. Dialogue, 10(2), 191. 